\title{
Karakterisasi Enzim Komersial Siklodekstrin Glukanotransferase
}

\author{
Characterization of Commercial Enzyme Cyclodextrin Glucanotransferase
}

\author{
Elidar Naiola* dan Nunuk Widhyastuti
}

Bidang Mikrobiologi, Puslit Biologi, LIPI.Gd. Herbarium, Cibinong Science Center, Cibinong 16911

E-mail: camplong2003@yahoo.com*Penulis untuk korespondensi

\begin{abstract}
The objective of this study is to investigate the characteristic of commercial enzyme Cyclodextrin Glucanotrasferase (CGTase) from Bacillus macerans. The CGTase was purified by dialysis, gel fitration and ion exchange chromatography. Study on Characterization of the enzyme showed that the hydrolytic activity of CGTase was $480 \mathrm{U} / \mathrm{mg}$, the optimum tempetature and $\mathrm{pH}$ for enzyme reaction were $45^{\circ} \mathrm{C}$ to $55^{\circ} \mathrm{C}$ and $\mathrm{pH} 5.0$ to 8.0 , respectively. The CGTase was relatively stable after heating at $55^{\circ} \mathrm{C}$ for 10 minutes, and maintained its activity at the pH 5.0 to 9.0. The enzyme activity was inhibited by the presence of $1 \mathrm{mM}$ metal ions and cause CGTase lost approximately $40 \%$ of its activity. Among the metal ions it was found that $\mathrm{Cu}^{2+}$ was the strongest inhibitor, with presence of $1 \mathrm{mM} \mathrm{Cu}{ }^{2+}$ the residual activity of CGTase was $24.4 \%$. Results of purification showed that Specific activities of the enzyme during purification were $269 \mathrm{U} / \mathrm{mg}$ (crude enzyme); $955 \mathrm{U} / \mathrm{mg}$ (dialysis); $481 \mathrm{U} / \mathrm{mg}$ (gel fitrations); and $544 \mathrm{U} / \mathrm{mg}$ (ion exchange chromatography).
\end{abstract}

Key words: Cyclodextrin Glucanotransferase, Bacillus macerans, purification, characterization

Diterima: 29 Januari 2008, disetujui: 17 April 2008

\section{Pendahuluan}

Siklodekstrin glukanotransferase $(1,4-\alpha-$ D-glukan 4- $\alpha$-D-glukan(1,4-glukano)transferase, siklik (CGTase) adalah suatu enzim yang memiliki aktivitas transglikosilasi atau dapat mentransfer gugus glikosil dari donor ke aseptor yang sesuai baik secara intermolekular maupun intramolekular. Disamping aktivitas transfer, CGTase juga memiliki kemampuan untuk menghidrolisis pati dan siklodekstrin menjadi senyawa yang lebih sederhana (Kometani et al., 1996). Siklodekstrin merupakan suatu senyawa siklik homolog dari oligosakarida yang tersusun atas 6, 7 atau 8 gugus glikosil dengan ikatan $\alpha-1,4$. Senyawa ini telah dimanfaatkan secara luas dalam industri, sebagai stabilisator, sebagai senyawa emulsifier, penghilang bau dan pengubah viskositas serbuk (Mori et al., 1994). Untuk meningkatkan solubilitas senyawa-senyawa flavonoid dilakukan dengan cara memindahkan suatu gugus tertentu dari senyawa donor pada senyawa flovonoid dengan bantuan enzim transferase (Kometani et al., 1990).

Berdasarkan jenis produk utama yang dihasilkan melalui reaksi transglikosilasi intramolekular, CGTase digolongkan menjadi 3 kelompok yaitu tipe yang dihasilkan Bacillus macerans yang menghasilkan $\alpha$ siklodekstrin, tipe yang dihasilkan Bacillus megaterium yang menghasilkan $\beta$ siklodekstrin dan tipe yang dihasilkan Bacillus sp. yang menghasilkan $\gamma$ siklodekstrin. Berat molekul CGTase dari Bacillus subtilis adalah 64.000, Bacillus formis adalah 75.000 dan Brevibacterium sp. adalah 75.000 (Mori et al., 1994).

Penelitian ini bertujuan untuk mempelajari beberapa karakter dari enzim kasar siklodekstrin glukanotransferase 
(CGTase) terutama kondisi optimum untuk reaksi enzimatisnya karena enzim CGTase banyak diaplikasikan dalam bentuk ekstrak kasar atau semi murni.

\section{Metode Penelitian}

\section{Enzim}

Enzim yang digunakan dalam penelitian ini adalah CGTase (Siklodekstrin Glukanotransferase) komersial yang dihasilkan oleh Bacillus macerans. Enzim ini masih merupakan "crude" atau enzim kasar yang diperoleh dari Jepang.

\section{Pengukuran aktivitas hidrolitik CGTase}

Aktivitas hidrolitik CGTase diuji dengan metoda yang digunakan oleh Mori et al., 1994 dan Rashid et al., 2002. Pada 0,5 ml substrat (1,5\% pati terlarut dalam 0,1 M bufer Atkins \& Pantin pH 9,0) ditambahkan $50 \mu \mathrm{l}$ larutan enzim (yang diencerkan 10 kali dengan menggunakan 0,1 M bufer Atkins \& Pantin pH 9,0) diinkubasikan pada suhu $40^{\circ} \mathrm{C}$ selama 30 menit. Kemudian pada larutan tersebut ditambahkan 5 $\mathrm{ml} 1 \mathrm{~N} \mathrm{HCl}$ untuk menghentikan reaksi enzimatis, dan ditambahkan $5 \mathrm{ml}$ larutan pewarna Iodine $(0,005 \%$ Iod dalam $0,05 \%$ larutan KI). Selanjutnya dibaca absorbansinya dengan spektrofotometer pada panjang gelombang $660 \mathrm{~nm}$. Satu unit aktivitas enzim dinyatakan sebagai banyaknya enzim yang dapat menurunkan unit absorbansi sebanyak 0,5 pada panjang gelombang $660 \mathrm{~nm}$.

\section{Pengaruh suhu terhadap aktivitas dan stabilitas CGTase}

Pengaruh suhu terhadap enzim CGTase diuji dengan cara mengukur aktivitas hidrolitik enzim pada berbagai suhu $(30,35,40,45,50,55$, 60, 65 dan $70^{\circ} \mathrm{C}$ ) selama 30 menit. Stabilitas CGTase terhadap suhu diuji dengan cara menginkubasikan larutan enzim pada pada berbagai suhu (35, 40, 45, 50, 55, 60, 65 dan $70^{\circ} \mathrm{C}$ ) selama 10 menit. Setelah inkubasi selesai, larutan enzim didinginkan dengan cepat pada permukaan es. Aktivitas enzim tersisa diukur pada kondisi standar pengujian aktivitas hidrolitik dan nilainya dinyatakan dalam persen terhadap aktivitas enzim tanpa perlakuan (Sulistyo et al., 2000).

\section{Pengaruh pH terhadap aktivitas dan stabilitas CGTase}

Untuk melihat pengaruh $\mathrm{pH}$ terhadap aktivitas enzim, pengukuran aktivitas CGTase dilakukan menurut cara yang sama, tetapi pengujian dilakukan dalam 0,1 M larutan bufer pada berbagai $\mathrm{pH}$. Larutan bufer yang digunakan adalah 0,1 $\mathrm{M}$ bufer Mc Ilvaine $\mathrm{pH}$ 3,0 - 7,0 dan 0,1 M bufer Atkins dan Pantin $\mathrm{pH}$ 8,0 - 11,0, selanjutnya ditambah dengan substrat (1,5\% pati terlarut). Stabilitas CGTase terhadap $\mathrm{pH}$ diuji dengan cara menginkubasikan larutan enzim dalam 0,1 M larutan bufer pada berbagai $\mathrm{pH}$ selama 1 jam dan 24 jam pada suhu kamar. Selanjutnya, aktivitas enzim tersisa diukur pada kondisi standar pengujian aktivitas hidrolitik dan nilainya dinyatakan dalam persentase terhadap aktivitas enzim tanpa perlakuan (Sulistyo et al., 2000).

\section{Pengaruh ion logam terhadap aktivitas enzim}

Pengaruh ion logam terhadap aktivitas enzim diuji dengan cara menginkubasikan larutan enzim dalam 0,1 M bufer Atkins dan Pantin pH 8,0 yang mengandung $1 \mathrm{mM}$ berbagai ion logam selama 10 menit. Senyawa logam yang digunakan adalah: $\mathrm{AgNO}_{3}, \mathrm{BaCl}_{2}$, $\mathrm{CaCl}_{2}, \mathrm{CdCl}_{2}, \mathrm{CoCl}_{2}, \mathrm{CuCl}_{2}, \mathrm{FeCl}_{3}, \mathrm{HgCl}_{2}$, $\mathrm{MgCl}_{2}, \mathrm{MnCl}_{2}, \mathrm{SnCl}_{2}, \mathrm{SrCl}_{2}, \mathrm{ZnCl}_{2}$. Aktivitas enzim diukur pada kondisi standar pengujian aktivitas hidrolitik enzim dan nilainya dinyatakan dalam persen terhadap aktivitas enzim tanpa perlakuan (Mori et al., 1994).

\section{Pemurnian CGTase}

Pemurnian enzim CGTase dilakukan pertama kali dengan cara dialisis, yaitu cara sederhana yang umum dilakukan untuk pemurnian enzim (Deutcher, 1990). Larutan enzim hasil dialisis selanjutnya diikuti filtrasi gel dengan menggunakan matrik DEAE Sephadex A50. Tingkat kemurnian enzim serta aktivitas spesifiknya ditentukan (Trevor, 1991). 


\section{Dialisis}

Larutan enzim CGTase kasar (produk komersial) didialisis dengan menggunakan membran dialisis yang memiliki molecular weight cutoff 14.000. Sebanyak 3-5 ml larutan enzim dimasukkan dalam membran dan didialisis dalam $500 \mathrm{~mL}$ bufer fosfat $0,05 \mathrm{M}$, $\mathrm{pH}$ 7,0 selama 24 jam pada suhu dingin yaitu sekitar $4^{0} \mathrm{C}$ (suhu dijaga tetap dingin untuk mencegah kerusakan enzim) menggunakan es yang diletakkan disekelilingnya. Penggantian bufer dilakukan sebanyak tiga kali masingmasing $500 \mathrm{ml}$.

\section{Pemurnian enzim dengan filtrasi gel}

Larutan enzim (5 ml) yang telah kromatografi (panjang $80 \mathrm{~cm}$, diameter $1,5 \mathrm{~cm}$ ) yang telah diisi dengan matriks Sephadex G100 yang sebelumnya telah diekuilibrasi dengan larutan 0,05 M bufer fosfat $\mathrm{pH}$ 7,0. Protein enzim dielusi dengan larutan bufer yang sama pada kecepatan aliran $0,5 \mathrm{ml} /$ menit. Setiap $3 \mathrm{ml}$ hasil elusi ditampung dan diukur absorbansinya dengan spektrofotometer pada panjang gelombang $280 \mathrm{~nm}$. Grafik pola elusi dibuat berdasarkan hasil pengukuran $\mathrm{OD}_{280}$ dan aktivitas CGTase (Smith, 1990).

\section{Pemurnian enzim dengan kromatografi pertukaran ion}

Larutan enzim hasil pemurnian dengan filtrasi gel selanjutnya dilewatkan ke dalam kolom kromatografi yang berisi matriks DEAE Sephadex A 50 yang sudah diekuilibrasi dengan 0,05 M larutan bufer fosfat $\mathrm{pH}$ 7,0. Untuk mengeluarkan protein atau senyawa lain yang tidak terikat oleh matriks, kolom dibilas dengan bufer yang sama (2x volume kolom), dan protein enzim yang diperkirakan terikat pada matriks dibilas dengan menggunakan gradien linier larutan $0,5 \mathrm{~N} \mathrm{NaCl}$ dengan kecepatan aliran 0,5 ml/menit. Setiap $3 \mathrm{ml}$ hasil elusi ditampung dan diukur absorbansinya pada panjang gelombang $280 \mathrm{~nm}$. Pola elusi dibuat berdasarkan hasil pengukuran $\mathrm{OD}_{280}$ dan aktivitas CGTase. Cara Pemurnian enzim dengan khromatografi penukar ion dilakukan menurut Smith (1990).

\section{Penetuan kadar protein enzim}

Protein enzim ditentukan menurut cara Bradford (1976).

\section{Hasil dan Pembahasan}

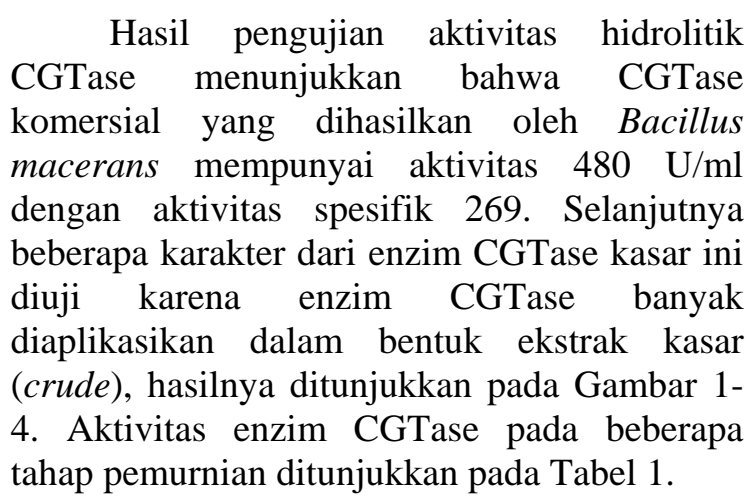

\section{Karakterisasi enzim}

\section{Pengaruh pH}

Dari data pada Gambar 1 dapat dilihat bahwa pada kondisi $\mathrm{pH}$ 3,0 dan $\mathrm{pH}$ 4,0 aktivitas enzim sangat rendah, yaitu masingmasing sebesar 3,125 U/ml dan 6,667 U/ml. Pada kisaran pH 5,0 - 8,0 aktivitas CGTase cukup tinggi yaitu berkisar antara 196,296 $\mathrm{U} / \mathrm{ml}$ - 198,642 U/ml. Sejalan dengan peningkatan $\mathrm{pH}$ larutan dari 8,0 sampai 9,0 aktivitas enzim mengalami penurunan sampai pada $\mathrm{pH}$ 11,0 dan aktivitas enzim sudah tidak terdeteksi.

Pengukuran aktivitas enzim terhadap $\mathrm{pH}$ (Gambar 2) menunjukkan bahwa CGTase dari Bacillus macerans kelihatannya relatif stabil pada kisaran $\mathrm{pH}$ 5,0 - 9,0, aktivitas relatif enzim pada kisaran $\mathrm{pH}$ tersebut adalah sekitar $95 \%$. Pada $\mathrm{pH}>9,0$, atau $<5,0$ stabilitas enzim tersebut mulai menurun. Lamanya inkubasi pada berbagai $\mathrm{pH}$ juga berpengaruh terhadap stabilitas CGTase. Setelah enzim diinkubasikan selama 1 jam pada $\mathrm{pH}$ 3,0, pH 4,0 dan $\mathrm{pH}$ 11,0 masih terlihat adanya aktivitas enzim yang tersisa, bahkan enzim masih menyisakan sekitar 90\% aktivitasnya setelah diinkubasikan pada $\mathrm{pH}$ 5,0 dan setelah diinkubasikan selama 24 jam pada $\mathrm{pH}$ tersebut enzim CGTase dari Bacillus macerans kehilangan seluruh aktivitasnya (Gambar 2).

Terjadinya penurunan aktivitas enzim sebagai akibat perubahan $\mathrm{pH}$ tidak terlalu 
besar. Menurut Palmer (1981), perubahan kondisi ion enzim dapat terjadi pada residu asam amino yang berfungsi katalitik dalam mengikat substrat maupun pada residu asam amino yang berfungsi untuk mempertahankan struktur tersier dan kwarterner enzim yang aktif. Aktivitas enzim yang mengalami penurunan dapat dipulihkan kembali dengan mengembalikan kondisi reaksi enzimatis pada
$\mathrm{pH}$ optimum. Pada $\mathrm{pH}$ yang sangat tinggi atau sangat rendah ( $\mathrm{pH}$ ekstrim) akan menyebabkan perubahan muatan ion pada rantai samping sehingga mengakibatkan terjadinya denaturasi enzim yang disertai dengan hilangnya aktivitas katalitik enzim. Disamping itu, perubahan struktur tersier menyebabkan terjadi kontak kelompok hidrofobik dengan air sehingga solubilitas dan aktivitas enzim menurun.

Tabel 1. Aktivitas enzim CGTase dengan berbagai cara pemurnian

\begin{tabular}{|c|c|c|c|c|c|c|c|}
\hline $\begin{array}{c}\text { Tahapan } \\
\text { purifikasi }\end{array}$ & $\begin{array}{l}\text { Total volum K } \\
(\mathrm{ml})\end{array}$ & $\begin{array}{l}\text { Kons. Protein } \\
(\mu \mathrm{g} / \mathrm{mL})\end{array}$ & $\begin{array}{l}\text { Total protein } \\
\text { (mg) }\end{array}$ & $\begin{array}{c}\text { Aktv. CGTase } \\
(\mathrm{U} / \mathrm{mL})\end{array}$ & $\begin{array}{l}\text { Total aktv. } \\
\text { (Unit) }\end{array}$ & $\begin{array}{c}\text { Aktv. Spesifik } \\
\text { (U/mg) }\end{array}$ & $\begin{array}{c}\text { Hasil } \\
(\%)\end{array}$ \\
\hline CGTase awal & 3 & 1784 & "5,352 & 480 & 1440 & 269 & 100 \\
\hline Dialisis & 5 & 286,6 & 1,433 & 273,6 & 1368 & 955 & 95 \\
\hline Filtrasi gel & 57 & 4,37 & 0,249 & 2,1 & 269 & 481 & 8,3 \\
\hline $\begin{array}{l}\text { Kromatografi } \\
\text { pertukaran ion }\end{array}$ & 40 & 19,87 & 0,745 & 10,8 & 119,7 & 544 & 30 \\
\hline
\end{tabular}

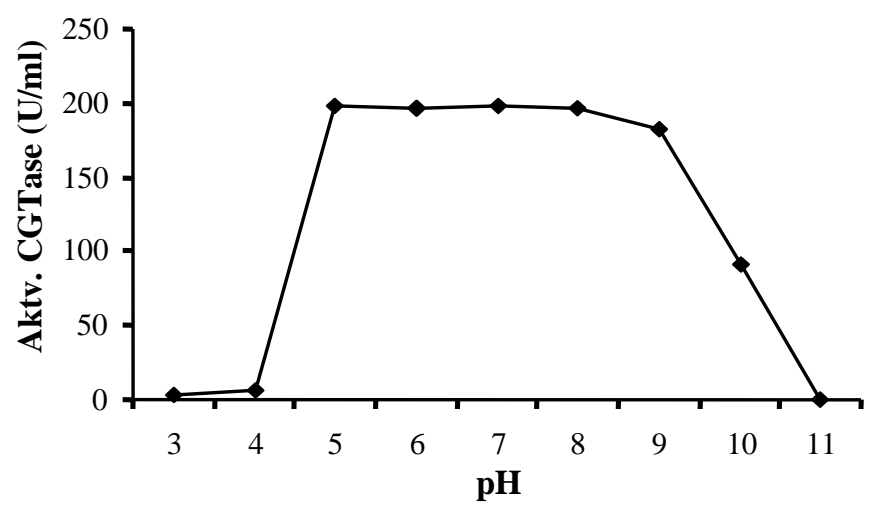

Gambar 1. Pengaruh pH terhadap aktivitas CGTase

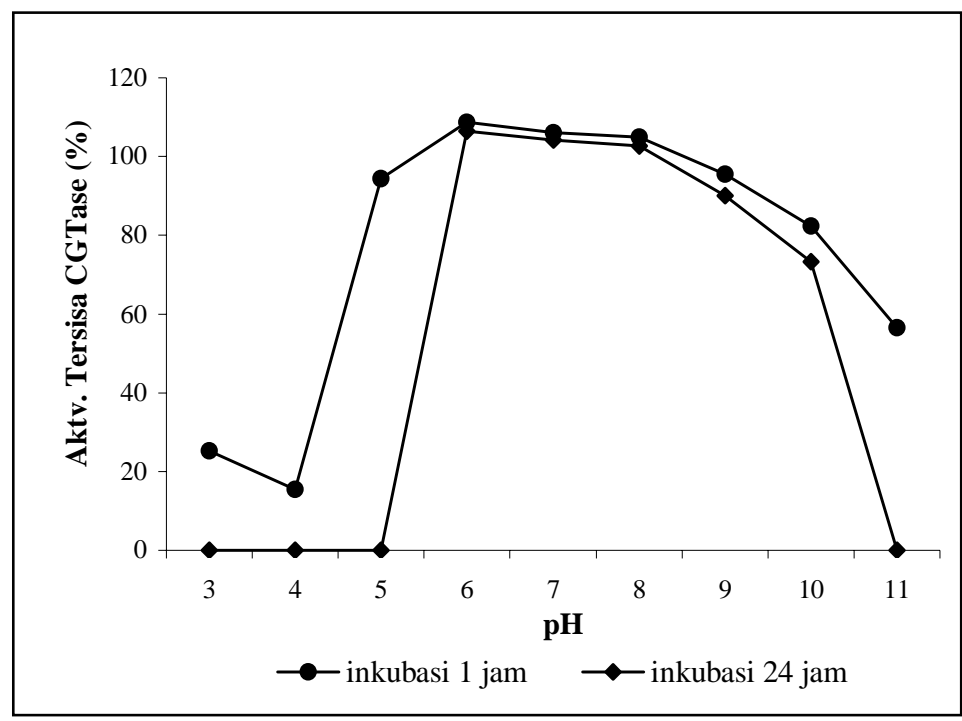

Gambar 2. Stabilitas CGTase terhadap pH 


\section{Pengaruh suhu}

Pengaruh suhu terhadap aktivitas dan stabilitas CGTase dari Bacillus macerans dapat dilihat pada Gambar 3 dan 4. Seiring dengan meningkatnya suhu reaksi sampai mencapai $50^{\circ} \mathrm{C}$, aktivitas CGTase juga semakin meningkat. Selanjutnya aktivitas enzim mulai menurun meskipun suhu dinaikkan, dan pada suhu $70^{\circ} \mathrm{C}$ enzim CGTase kehilangan aktivitasnya. Aktivitas optimum CGTase adalah pada kisaran suhu $45^{\circ} \mathrm{C}-55^{\circ} \mathrm{C}$.
Tampaknya enzim CGTase dari Bacillus macerans merupakan enzim yang cukup stabil terhadap perlakuan pemanasan (Gambar 4).

Setelah enzim diinkubasi pada suhu $55^{\circ} \mathrm{C}$ selama 10 menit, aktivitas enzim tersisa masih sekitar $88,4 \%$ dan pada suhu $60^{\circ} \mathrm{C}$ sekitar $60 \%$. Menurut Harper et al., (1984), terjadinya peningkatan aktivitas enzim dibawah suhu optimum disebabkan oleh meningkatnya energi kinetika dari molekul-molekul yang bereaksi (meningkatnya frekuensi tumbukan) sebagai akibat kenaikan suhu reaksi.

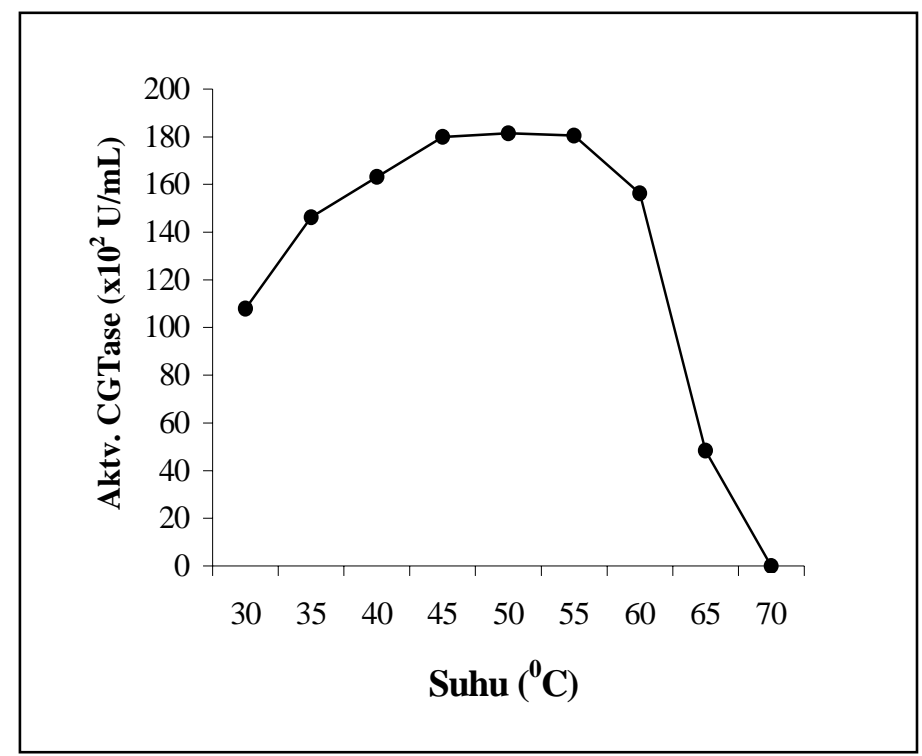

Gambar 3. Pengaruh suhu terhadap aktivitas CGTase

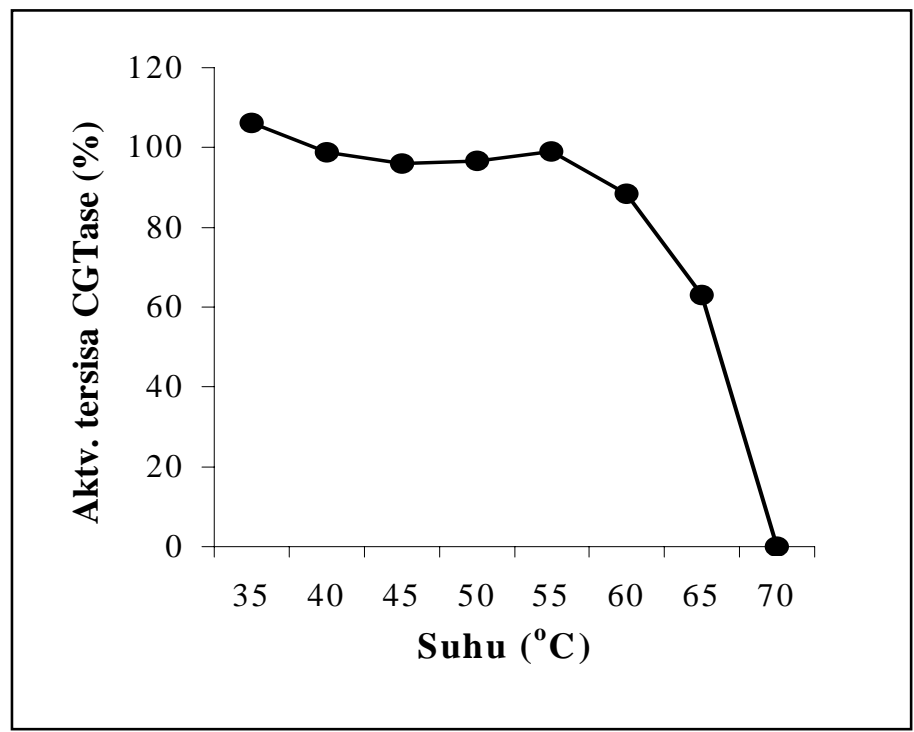

Gambar 4. Stabilitas CGTase terhadap suhu 
Terjadinya penurunan aktivitas enzim pada keadaan diatas suhu optimum adalah disebabkan oleh terputusnya ikatan sekunder enzim karena besarnya energi kinetika dari molekul enzim. Putusnya ikatan sekunder pada keadaan katalitik aktif akan mengakibatkan hilangnya struktur sekunder dan tersier dari enzim, disertai dengan hilangnya aktivitas enzim. Pada suhu yang tinggi, substrat juga dapat mengalami perubahan konformasi sehingga tidak dapat memasuki sisi aktif enzim (Suhartono, 1989). CGTase dari Bacillus macerans sedikit lebih tahan terhadap pemanasan jika dibandingkan dengan CGTase yang dihasilkan Brevibacterium sp. No.9605 (Mori et al., 1994). Setelah inkubasi pada suhu $55^{\circ} \mathrm{C}$ selama 10 menit dalam larutan bufer Atkins dan Pantins pH 8,0, CGTase dari Bacillus macerans masih memiliki aktivitas relatif sebesar 88,37\%, sedangkan untuk Brevibacterium sp No.9605 hanya sekitar 50\%.

\section{Pengaruh ion logam}

Pengaruh ion logam terhadap aktivitas CGTase dapat dilihat pada Gambar 5. Reaksi enzimatis dari CGTase yang tampak dipengaruhi ion-ion logam. Setelah diinkubasikan selama 10 menit dalam 0,1 M bufer Atkins dan Pantin yang mengandung 1 $\mathrm{mM}$ masing-masing ion logam terlihat dapat menyebabkan penurunan aktivitas 30-40\%. Diantara ion-ion tersebut, ion $\mathrm{Cu}^{2+}$ merupakan inhibitor CGTase yang paling kuat karena setelah diinkubasikan selama 10 menit dalam 0,1 M bufer Atkins dan Pantin aktivitas CGTase yang tertinggal sekitar seperempatnya. Pengaruh ion logam terhadap aktivitas CGTase dari Bacillus macerans tampak agak berbeda dibandingkan dengan aktivitas CGTase dari Brevibacterium sp. N0.9605. Aktivitas CGTase dari Brevibacterium sp. No.9605 sangat dihambat oleh adanya $\mathrm{ZnCl}_{2}, \mathrm{AgNO}_{3}, \mathrm{CuCl}_{2}$, $\mathrm{CdCl}_{2}$, bahkan adanya $\mathrm{HgCl}_{2}$ menyebabkan aktivitas CGTase hilang. Untuk senyawa logam yang lain relatif tidak berpengaruh terhadap aktivitasnya (Mori et al., 1994).

\section{Pemurnian CGTase}

Aktivitas hidrolitik CGTase (enzim pada awal pemurnian) menunjukkan bahwa CGTase komersial yang dihasilkan oleh Bacillus macerans mempunyai aktivitas $480 \mathrm{U} / \mathrm{ml}$ dengan aktivitas spesifik $269 \mathrm{U} / \mathrm{mg}$. Selanjutnya, pemurnian enzim CGTase dilakukan pertama kali dengan cara dialisis diikuti filtrasi gel dan kromatografi pertukaran ion. Tingkat kemurnian enzim serta aktivitas spesifiknya pada tahap-tahap pemurnian ditentukan.

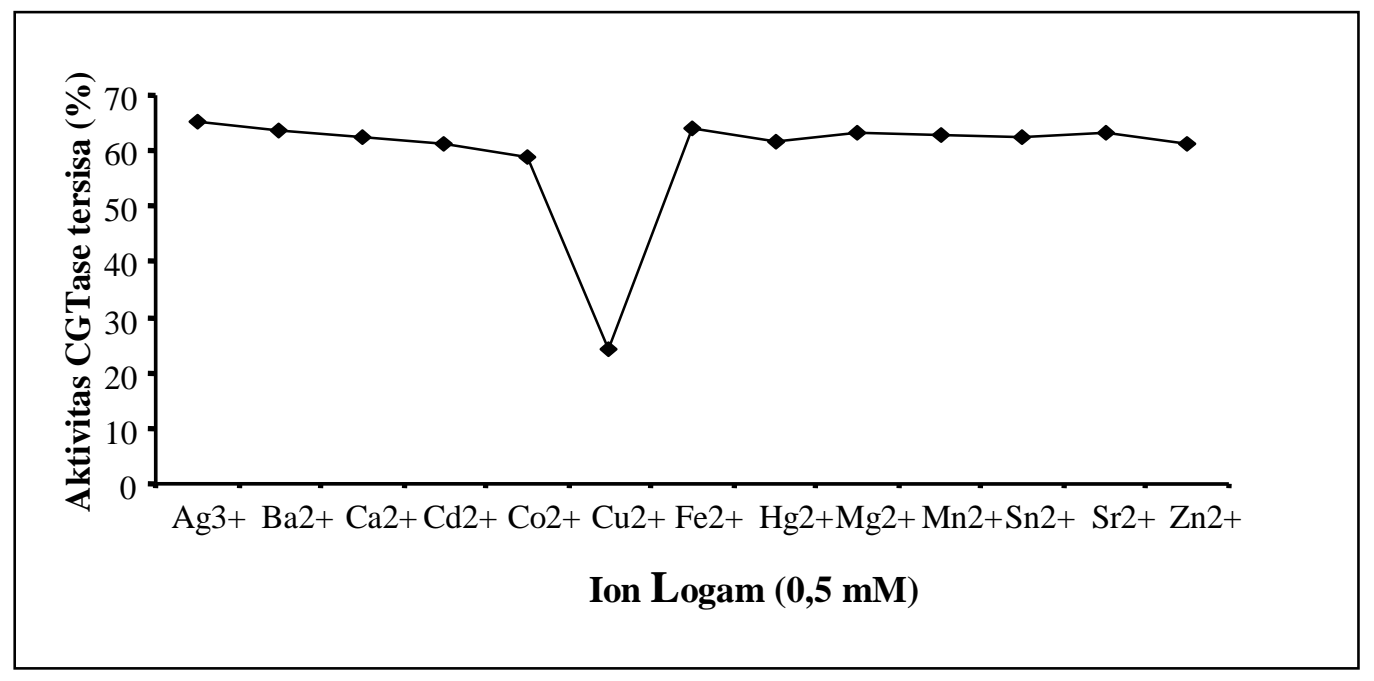

Gambar 5. Pengaruh berbagai ion logam terhadap aktivitas CGTase 


\section{Dialisis}

Hasil pada dialisis terhadap enzim awal adalah sebesar 95\% (Tabel 1). Enzim hasil dialisis berikutnya dimurnikan dengan cara filtrasi gel melalui kolom berisi matrik Sephadex G 100 dan dibilas dengan larutan 0,05 M bufer larutan Atkin \& Pantin's pH 7,8. Filtrasi gel adalah suatu teknik memisahkan zat-zat berdasarkan ukuran molekulnya. Pemisahan terjadi antara fase cair di dalam partikel dan cairan yang mengelilingi partikel gel. Akibat dari perbedaan laju permeasi masing-masing molekul zat terlarut maka terjadi pemisahan. Dengan cara filtrasi gel (melalui kolom berisi matrik Sephadex G 100) yang dibilas dengan larutan 0,05 M larutan Atkin \& Pantin's pH 7,8 protein yang memiliki berat molekul lebih rendah akan terbilas lebih dahulu. Hasil elusi memperlihatkan adanya dua puncak utama protein, satu diantaranya adalah protein enzim CGTase yaitu dari fraksi $22-29$ dengan aktivitas spesifik sebesar $481 \mathrm{U} / \mathrm{mg}$, sedang satu puncak lainnya tidak memperlihatkan adanya aktivitas enzim CGTase.

Fraksi yang mengandung enzim CGTase setelah digabungkan (fraksi $22-29 \mathrm{U} / \mathrm{mg}$ ), dimurnikan lebih lanjut dengan menggunakan kromatografi penukar ion yaitu dengan cara melewatkannya pada kolom berisi matrik DEAE Sephadex A50. Protein yang terikat dibilas dengan gradien linier $0-0,5 \mathrm{M} \mathrm{NaCl}$ dalam bufer Atkin dan Pantin's pH 7,8. Penentuan aktivitas spesifik setiap fraksi penting untuk menentukan tingkat kemurnian (Trevor, 1991). Aktivitas spesifik CGTase setelah melalui khromatografi penukar ion meningkat dari $481 \mathrm{U} / \mathrm{mg}$ menjadi $544 \mathrm{U} / \mathrm{mg}$. Hasil yang ditemukan setelah melalui khromatografi penukar ion terhadap enzim awal adalah sebesar 30\%.

\section{Kesimpulan}

\footnotetext{
Berdasarkan hasil penelitian dapat disimpulkan bahwa siklodekstrin glukanotransferase (CGTase) komersial yang dihasilkan oleh Bacillus macerans mempunyai aktivitas hidrolitik $480 \mathrm{U} / \mathrm{ml}$. Aktivitas optimum CGTase pada $\mathrm{pH} 5,0-8,0$ dan suhu $45-55^{\circ} \mathrm{C}$.
}

Stabilitas CGTase dicapai pada kondisi pH 5,09,0. Enzim ini relatif stabil terhadap pemanasan pada suhu $55^{\circ} \mathrm{C}$ selama 10 menit. Ion-ion logam dapat menyebabkan penurunan aktivitas CGTase sampai $60 \%$. Ion $\mathrm{Cu}^{2+}$ merupakan ion logam yang paling menghambat aktivitas CGTase. Aktivitas spesifik protease krude enzim adalah $269 \mathrm{U} / \mathrm{mg}$; hasil dialisis 955 $\mathrm{U} / \mathrm{mg}$, fitrasi gel $481 \mathrm{U} / \mathrm{mg}$ dan kromatografi penukar ion $544 \mathrm{U} / \mathrm{mg}$.

\section{Ucapan Terima Kasih}

Ucapan terima kasih penulis sampaikan kepada Dr. Joko Sulistyo yang telah memberikan dorongan moril, literatur dan bahan penelitian kepada penulis.

\section{Daftar Pustaka}

Bradford, M.M. 1976. A Rapid and Sensitive Method for the Quantitation of Microgram Quantities of Protein Utilizing the Principle of Protein-Dye Binding. Anal. Biochem. 72: 248-254.

Deutscher, P.M. 1990. Methods in Enzymology. 182. Academic Press Inc., New York, 285-289.

Harper, H.A., Rodwel, V.W. and Mayer, P.A. 1984. Review of Physiological Chemistry. Lenge Medical Publication, California USA.

Kometani, T., Yoshinobu, T., Takashi, N., Hiroshi, T. and Shigetaka, O. 1990. Transglycosylation to hesperidin by cyclodextrin glucanotransferase from an alkalophilic Bacillus species in alkaline $\mathrm{pH}$ and properties of hesperidin glycosides. Biosci.Biochem. 58 (11): 19901994.

Kometani, T., Yoshinobu, T., Takashi, N., Hiroshi, T. and Shigetaka, O. 1996. Acceptor specificity of cyclodextrin glucanotransferase from an alkalophilic Bacillus species and synthesis of glycosyl rhamnose. Biosci. Biotech. Biochem. 60 (7): 1176-1178.

Mori, S., Susumu, H., Takaichi, O. and Sumio, K. 1994. Purification and properties of of cyclodextrin glucanotransferase from Brevibacterium sp. No.9605. Biosci. Biotech. Biochem. 58 (11): 1968-1972.

Palmer, T. 1981. Understanding enzymes. Ellis Horwood Ltd. England. p.76. 
Rashid, N., Cornista, J., Ezaki, S., Fukui, T., Atomi, H. and Imanaka, T. 2002. Characterization of an Archaeal Cyclodextrin Glucanotransferase with a Novel C-Terminal Domain. J. of Bacteriology 184 (3): 777-784.

Suhartono, M.T. 1989. Enzim dan bioteknologi. PAU-IPB. pp.71-75.

Sulistyo, J., Dinoto, A., Choliq, A. dan Soeka, Y.S. 2000. Mikroba Indigen Penghasil Enzim dengan Aktivitas Transglikolasi. Mikrobiologi, Enzim dan Bioteknologi dalam Perspektif Ekonomi dan Industri. Pros. Sem. Nas. Industri Enzim dan Bioteknologi II. Jakarta.

Smith, E.J. 1990. Biotechnology Priciple, Terjemahan Usman, F.S., Bambang, S. dan Agung, S. PT Gramedia, Jakarta. 132- 135; 182-183.

Trevor, P. 1991. Understending Enzyme, $3^{\text {rd }}$ Ed. Elis Harwood, New York, pp. 306-307. 